\title{
WOULD FAST SAILING TOWARDS THE EURO BE SMOOTH? WHAT FUNDAMENTAL REAL EXCHANGE RATES TELL US
}

\author{
Kateřina ŠMÍDKOVÁ*, Aleš BULÍŘ **
}

\begin{abstract}
:
Computed fundamental real exchange rates in four new EU members point to difficulties in jointly entering the ERM II soon after the EU entry. Three currencies out of the four were overvalued prior to EU entry. Computations suggest that it is unlikely that the Czech, Hungarian and Polish economies will maintain low inflation during $2004-2010$ and at the same time keep their currencies within the ERM II easily. Moreover, the experience of Greece, Portugal and Spain - viewed through fundamental real exchange rate goggles - indicates more stable real exchange rate paths and smaller currency misalignments prior to euro adoption than can be expected from the newcomers in the forthcoming years. If the newcomers sail too fast towards the euro, their sailing may not be as smooth as that of the front runners.
\end{abstract}

Keywords: fundamental real exchange rates, foreign direct investment, euro, acceding economies

JEL Classification: F31, F33, F41, F47

\section{Introduction}

European Union (EU) countries are put to several tests before they are allowed to introduce the euro. These tests will have to be passed by the countries that joined the EU in May 2004. When their prospects of passing the tests fast and smoothly are being evaluated, the possible conflict between the trend appreciation of real

*) Czech National Bank, Na Př́́kopě 28, CZ - 11503 Prague 1 (e-mail: smidkova @ cnb.cz).

$\left.{ }^{\star \star}\right)$ International Monetary Fund, $70019^{\text {th }}$ St. NW. Washington, DC 20431 (e-mail: abulir@imf.org).

$\left.{ }^{* \star \star}\right)$ The support of the Czech National Bank is gratefully acknowledged. The authors would like to thank I. Angeloni, R. Barrell, C. Detken, B. Égert, R. Driver, D. Holland, M. Mandel and seminar participants at the Czech National Bank for comments and suggestions. The views expressed in the paper are those of the authors, and do not represent those of the Czech National Bank and the International Monetary Fund. 
exchange rates observed so far in the newcomers, and the required low inflation and stable exchange rate is often discussed. In addition, there is another issue at stake. If a currency were to be irrevocably fixed at an improper parity to the euro, the misalignment would have to be adjusted through other, more costly processes, such as domestic price or wage adjustment. Locking currencies into an exchange rate regime with the euro too early could remove the shock-absorbing role of monetary and exchange rate policies before the process of real convergence moves sufficiently forward. The question we address in this paper can be simplified as follows: Is the volatile process of real exchange rate appreciation in the former transition countries over, making fast euro adoption trivial, or is it likely to continue for a few more years resulting in a potentially costly adjustment? In addition, we examine if there were indications of currency misalignment in the "newcomers" prior to EU entry.

The stylised facts regarding the four newcomers - the Czech Republic, Hungary, Poland and Slovenia - and the three "front runners" that joined the EU in the 1980s - Greece, Portugal and Spain - suggest that the newcomers need to worry about real appreciation much more than the front runners did prior to their euro adoption. This is being said under the assumption that the newcomers adhere to their pre-announced schedules and join the euro area around $2007-2010$, and hence that the current experience of the newcomers is comparable to that of the front runners in the early 1990s. Between 1998 and 2003, the average real appreciation was 2.7 per cent in our group of newcomers, while the front runners faced only 0.2 per cent real appreciation on average in the comparable period of $1992-1997$. We see foreign direct investment $(F D I)$ as the main culprit in explaining the real exchange rate appreciation in the four newcomers, which is otherwise at odds with alternative explanations such as the Balassa-Samuelson and external-wealth accumulation effects. Due to massive inflows of $F D I$, the four newcomers accumulated FDI of 25 per cent of GDP on average prior to EU entry. FDI also played an important role in the economic convergence process of the front runners, although in their case the stock of FDI amounted to only 10 per cent of GDP on average in 1997. We also noticed some surprising post-adoption developments in the front runners which may have interesting repercussions for the newcomers. FDI inflows slowed down following adoption of the euro. At the same time, the current account deficits of the front runners deepened and their net external liabilities increased. Should a similar slowdown of FDI inflows materialise, it is unclear whether the newcomers will be able to accumulate foreign liabilities in a fashion comparable to the front runners, given their already relatively high levels of external debt. We apply the concept of the fundamental real exchange rate (FRER) in order to analyze the real exchange rates of the newcomers and front runners. The FRER model was developed to measure how far the real exchange rates of economies converging to the euro area level of economic development are from the values corresponding to their economic fundamentals, and to estimate the sustainable path for real exchange rates in the medium run.

The FRER model has two specific features distinguishing it from other models of sustainable, desirable or equilibrium real exchange rates. First, it is the only one emphasising the role of $F D I$ in determining what speed of real appreciation can be explained by economic fundamentals. Second, the FRER model's definition is country specific and is based on stocks rather than flows. By employing a less binding definition of external balance, current account deficits can be relatively high and still be in line with fundamental real exchange rates (FRERs) during a period of economic convergence. This corresponds to our intuition that the catch-up process is likely to be at its fastest in the pre-euro period, and that as a result, current account deficits may exceed the conventionally assumed limit of $2-4$ per cent of GDP. 
However, temporarily larger deficits are only compatible with FRERs for those converging economies that have not inherited an excessive stock of external debt.

After the FRERs are computed under the baseline assumptions, extensive sensitivity tests and comparisons with other papers assessing the real exchange rates of the newcomers are performed. Regarding the former, confidence bands are derived for both in-sample and off-sample projection periods. While the in-sample confidence bands are calculated using the trade equation estimation errors, the off-sample confidence bands reflect in addition the historical standard errors of exogenous variables and uncertainty about the target value of external debt. The resulting confidence bands are of a similar order as those in other studies on equilibrium real exchange rates. Regarding the latter, the results are compared with recent studies. The FRER estimates of misalignment are of similar sign and magnitude when compared to other studies relying on analogous methodologies. A similar robustness check could not be made for the off-sample projections, since this issue has not been explicitly addressed in comparable research on the newcomers.

The computations of FRERs in the four newcomers point to difficulties in entering the ERM II mechanism soon after EU entry. Of the four countries, all the currencies but the Slovenian one were overvalued prior to EU entry. An early fixing visà-vis the euro could increase the likelihood of external imbalance and unsustainable exchange rate developments in all countries but Slovenia. Looking ahead, meeting the euro tests of exchange rate stability could be costly, owing to only gradual convergence of the equilibrium real exchange rates toward the narrow band. The computed FRERs suggest that it is unlikely that the Czech, Hungarian and Polish economies will maintain low inflation during $2004-2010$ and at the same time keep their currencies within the ERM II, especially if the strict definition of the ERM II is applied. Moreover, the experience of the front runners indicates smaller currency misalignments and more stable real exchange rate paths prior to euro adoption than can be expected from the newcomers in the forthcoming years. Hence, the benefits of the well-publicised "race to the euro" appear to be doubtful from this perspective. If the newcomers sail too fast towards the euro, their sailing may not be as smooth as that of the front runners.

The paper is organized as follows. Section 2 presents some stylised facts about the newcomers and the front runners. Section 3 summarises the methodological background and outlines the second generation of the FRER model. Section 4 explains the baseline computations and sensitivity tests. Section 5 shows empirical results for both the newcomers and the front runners. The final section concludes.

\section{Stylised Facts}

Our analysis is motivated by a few stylised facts regarding the four newcomers the Czech Republic, Hungary, Poland and Slovenia - that joined the EU in May 2004 and three countries that joined the EU in the 1980s - Greece, Portugal and Spain which we will call the front runners. ${ }^{1)}$ The front runners had had experience similar to that of the newcomers, which went through the process of economic transformation in the 1990s. Among the common features, political and economic reforms and

1) We focus on those four acceding countries - the Czech Republic, Hungary, Poland and Slovenia for which consistent data and country models are available from the National Institute Global Econometric Model (NiGEM). NiGEM contains country models of the analyzed acceding economies as well as models of all their trading partners. Hence, the computations of FRERs have a consistent macroeconomic framework (see Barrell et al., 2002). 
real economic convergence processes are worth mentioning. However, the two groups did not plan to adopt euro with the same speed. The front runners had had twice as much time to prepare for euro adoption than newcomers scheduled for themselves. Prior to their EU entry, the Czech Republic, Hungary, Poland and Slovenia announced in their euro-strategies or Pre-Accession Economic Programmes (PEPs) that they would like to join the euro area around $2007-2010$, that is three to six years after joining the EU. Greece joined the EU in 1981 and Portugal and Spain in 1986. Portugal and Spain introduced ERM II at the beginning of the 1990s and Greece in 1998. Portugal and Spain introduced the euro thirteen years after joining the EU, in 1999. Greece followed suit in 2001, twenty years after joining the EU. In order to sail as smoothly into the euro area as the front runners did, the newcomers should be prepared for euro adoption in 2004 as the front runners were in the second half of the 1990s. However, the selected stylised facts suggest that this may not be entirely true. Hence, their sailing towards the euro may not be as smooth.

The newcomers' currencies appreciated substantially in real terms during the last decade (Figure 1). On average, between 1992 and 2003, real exchange rates in the newcomers appreciated by 3.3 per cent. Between 1998 and 2003, the average real appreciation was 2.7 per cent. Prior to adopting the euro, the front runners appeared to fit a similar pattern, but on a much smaller scale. The front runners had to put up with real appreciation of 0.4 per cent on average between 1992 and 2003. In the period 1992 - 1997, the average real appreciation was 0.2 per cent. Under the assumption that the pre-announced schedules for euro adoption are adhered to, the newcomers should worry about real appreciation ten times more than the front runners did in the comparable time span. In the case of the four newcomers, the bulk of the real appreciation was effected through an inflation differential, as one might expect if the Balassa-Samuelson effect were significant. However, in the case of the newcomers, price deregulation contributed to changes in relative prices as well. In addition, a part of the early real appreciation resulted from a massive devaluation at the start of the transition process. ${ }^{2)}$ On average, inflation rates were 14.4 per cent between 1992 and 2003, and lower - around 6 per cent - during $1998-2003$. The nominal effective exchange rates showed a modest tendency to depreciate. On average, the nominal depreciation rate was 6 per cent between 1992 and 2003 and 1.7 during $1998-2003$. On the other hand, the inflation rates of the front runners reached lower levels, at 4.5 per cent between 1992 and 2003 and 2.8 per cent during 1998 - 2003. Their nominal effective exchange rates showed a tendency to appreciate. On average, the nominal appreciation was 6.6 per cent between 1992 and 2003 and 12.6 per cent during 1992 - 1997.

We see $F D I$ as the main culprit in explaining the real exchange rate appreciation in the four newcomers, which is otherwise at odds with alternative explanations such as the Balassa-Samuelson and external-wealth accumulation effects. The previous empirical work related to $F D I$ in the former transition countries (see Lansbury, Pain, Šmídková, 1996) supports this view. Prior to the EU enlargement, the four newcomers accumulated $F D I$ at an admirable level of 25 per cent of GDP on average (Figure 2). Massive FDI inflows may have affected investors' perception about these countries' long-term sustainable external balances. For example, if exports are driven primarily by $F D I$ - as compared to competitiveness of their exchange rates contemporaneous capital inflows may signal expected future net exports consistent with appreciated real exchange rates (see Benáček et al., 2003). FDI also played

2) See Halpern, Wyplosz (1997). They suggest that in the first half of the 1990s real effective exchange rates were undervalued relative to their equilibrium level in the four acceding economies. 
Figure 1

Inflation and Real and Nominal Effective Exchange Rates (1992 - 2002)
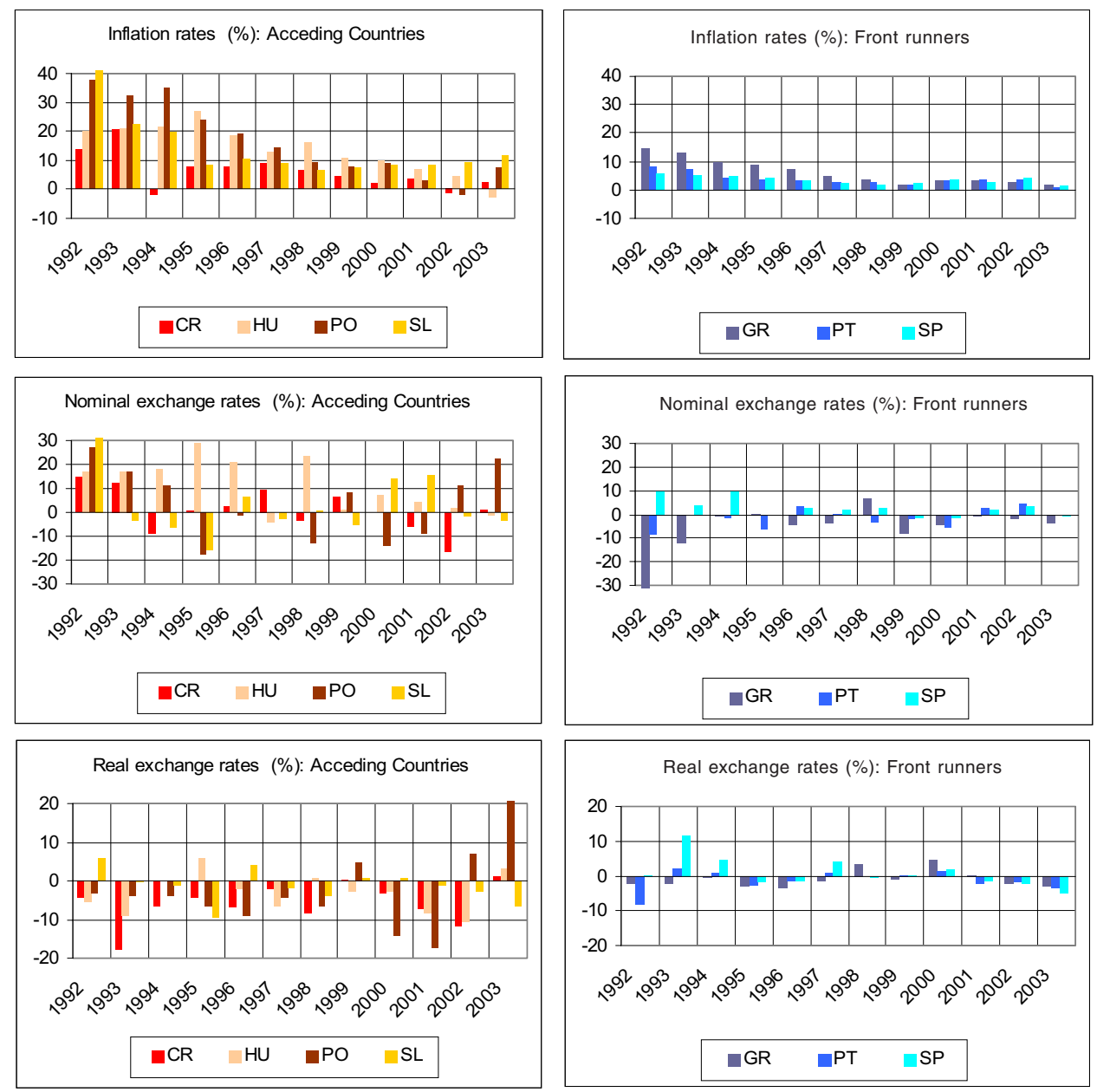

Note: All indicators are shown in percentage changes. Positive values of percentage changes in real and nominal effective exchange rates correspond to real and nominal currency depreciation respectively.

Sources: National Institute Global Econometric Model (NiGEM), national central banks.

Abbreviations: the Czech Republic (CR), Hungary (HU), Poland (PO), Slovenia (SL), Greece (GR), Portugal (PT), Spain (SP).

an important role in the economic convergence process of the front runners, although their stock of $F D I$ amounted on average to only 10 per cent of GDP in 1997.

Most empirical papers agree that rising total factor productivity in the tradable-goods sector (the Balassa-Samuelson effect) has been of second-rate importance in explaining the gradual and long-lasting real exchange rate appreciation in the former transition countries (see De Broeck, Sløk, 2001; Égert, 2002b; Mihaljek, 2002 , and Flek et al., 2003). Productivity gains in the traded-goods sector seem to explain but a minor fraction of the observed real appreciation. The observed appre- 
ciation cannot be explained away by the traditional argument of external wealth accumulation either (see Lane, Milesi-Ferretti, 2000, 2002). According to that hypothesis, countries with sizeable external liabilities need to run large trade balance surpluses to service those liabilities, and positive net exports require by definition a "competitive", that is, depreciated real exchange rate.

Figure 2

Net Foreign Assets, FDI and Current Account Deficits
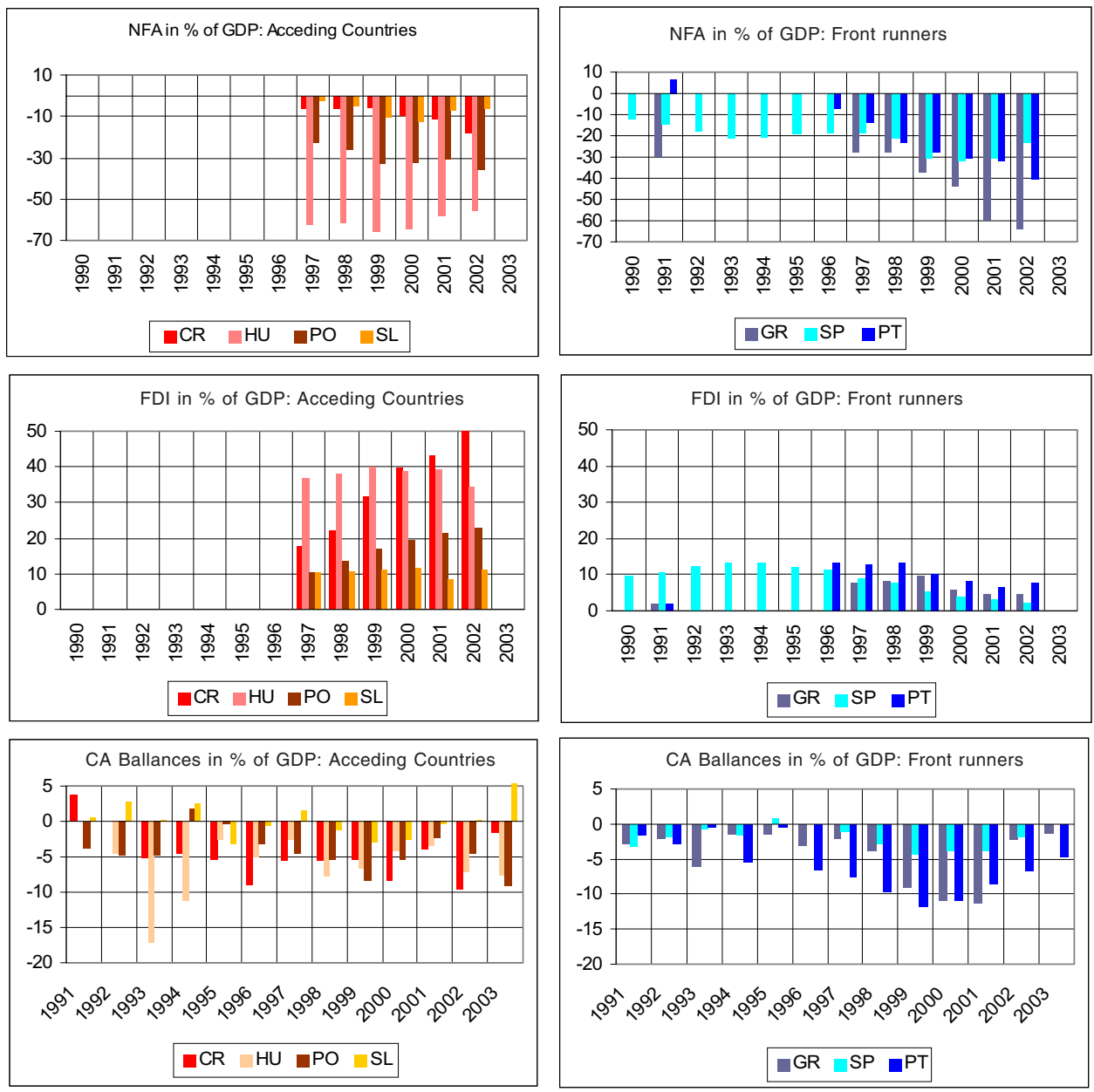

Note: All indicators are shown in percent of GDP. Data on stocks of net foreign assets and FDI are not available for every period.

Sources: NiGEM, national central banks, IMF BOP Year-books, Rider (1994).

Abbreviations: the Czech Republic (CR), Hungary (HU), Poland (PO), Slovenia (SL), Greece (GR), Portugal (PT), Spain (SP).

Contrary to this theory, the four newcomers have piled up external liabilities their net foreign assets (NFA) were negative and increasing prior to the EU entry and, at the same time, have run persistent current account deficits accompanied with 
real exchange rate appreciation. On average, their current account deficits were 4 per cent of GDP between 1992 and 2003, and their net foreign liabilities converged on average to nearly 30 per cent of GDP. The front runners also learned to live with current account deficits, on average 4 per cent of GDP between 1992 and 2003. However, during the run-up to the euro, their current account deficits were approximately half the size of those of the newcomers, around 2.4 per cent of GDP between 1992 and 1997 on average. Like the newcomers, the front runners accumulated nonnegligible net foreign liabilities, around 20 per cent of GDP on average in 1997.

To sum up, one decade prior to adopting the euro, the front runners appeared to fit similar patterns to those of the newcomers, but on much smaller scales. Real exchange rates appreciated, net foreign assets (NFAs) were negative, to some extent owing to $F D I$ inflows, and the countries ran current account deficits. However, due to the larger scale of these patterns, the four newcomers need to pay much closer attention to the consequences of real appreciation for the economy and to the implications of their current account deficits for their already decreasing NFAs. The motivation given by the stylised facts can be simplified into the following two questions. First, is the volatile process of real exchange rate appreciation in the former transition countries over making fast euro adoption trivial, or is it likely to continue for a few more years resulting in potentially costly adjustment in those countries? Second, is there an additional risk to sustainable economic development due to currency misalignment if ERM II is introduced soon after EU entry? The post-adoption experience of the front runners has interesting repercussions for the newcomers. First, the stock of net FDI declined following adoption of the euro. In 2003, it decreased to 5 per cent of GDP on average. Should a similar FDI slowdown occur in the newcomers, it would limit the expected integration gain restricting real convergence. Second, current account deficits deepened and growth in net foreign liabilities accelerated as a result. In 2003, the front runners accumulated net foreign liabilities of 40 per cent of GDP on average. This accelerated accumulation was possible in part because the stock of debt was relatively low prior to euro adoption. However, the existing external debt is comparatively higher in the four newcomers and any future increases are unlikely to be sustained, especially if the integration gain is less than what was expected by the financial markets.

\section{The Model Framework}

In this paper, the concept of the fundamental real exchange rate (FRER) is used to analyze the real exchange rates of the newcomers and front runners. It was developed to measure how far the real exchange rates of acceding economies converging to the euro area level of economic development are from values corresponding to their economic fundamentals, and to project the sustainable path for their real exchange rates in the medium run. This section summarises the benchmark studies in which the FRER concept is rooted. These studies work with various concepts of sustainable real exchange rates (SRERs). We call the whole group of alternative concepts "sustainable" real exchange rates since they all measure whether observed real exchange rates are (or will be) on a sustainable path with regard to external balance. We point out important differences between the FRER and alternative concepts. In the second part, we describe the actual model used for the FRER computations. 


\subsection{Sustainable and Fundamental Real Exchange Rates}

The concept of SRERs goes back to the research of Artus (1977). Since then, new methodological and empirical studies have emerged on a massive scale every time changes in exchange rate regimes have been debated. In the first half of the 1990s, a new design of the international exchange rate system was debated among economists. It was also a period when unsustainable developments in various economies with fixed exchange rate regimes were identified. These policy issues motivated an extremely rich branch of research. Barrell, Wren-Lewis (1989) computed fundamental equilibrium exchange rates for the G7 group. Artis, Taylor (1993) proposed a concept of desired equilibrium exchange rates reflecting fiscal policy targets. Williamson (1994) compared several approaches to estimating equilibrium exchange rates. Stein and Allen (1995) described fundamental determinants of real exchange rates. MacDonald (1999) emphasised the distinction between long-run and short-run fundamentals.

In these benchmark studies, the outcomes of the computations are often called equilibrium real exchange rates. Different adjectives, such as fundamental, desirable and behavioural, emphasise various methodological specifics. Alternative SRER concepts take different approaches to the role of economic policies and to the selection of economic fundamentals. SRERs also assume different concepts of equilibrium. Driver and Westaway (2003) explain how the alternative methodologies work with different time horizons, the three main approaches being single-equation estimates, normative-target based models and general equilibrium models. They relate to the short run, medium run and long run respectively. We suggest that mediumrun concepts are most suitable for analyzing the real exchange rates of the newcomers, given that their entry into the euro area will happen in a corresponding time span. When the international policy debate turned to the acceding economies and their pre-euro exchange rate regimes, numerous empirical studies emerged that tried to assess the real exchange rates of the newcomers. In his comprehensive survey, Égert (2003) quotes more than fifty studies related to the topic. They are all rooted in the previous stage of the policy debate about exchange rate regimes, as outlined above. SRERs were initially estimated for industrial countries (see Artis, Taylor, 1993; Feyzioğlu, 1997), and subsequently extended to developing countries (see Elbadawi, Soto, 1997; Mongardini, 1998 and MacDonald, Ricci, 2003) and to the former transition economies (see Halpern, Wyplosz, 1997; De Broeck, Sløk, 2001; Égert, 2002a, 2002b; Frait, Komárek, 2001 and Rahn, 2003). The FRER concept itself was first suggested in Šmídková, Barrel, Holland (2002). It has been argued that it better reflects some specific features of the former transition economies, such as convergence with significant help from FDI and relatively large current account deficits, with external indebtedness corresponding to safety limits. The FRER model relies on previous empirical work that focused on developing macro-models of acceding economies. ${ }^{3)}$ In this paper, the so-called "first-generation" FRER model is extended with a country specific definition of external balance and then newly applied to both the newcomers and the front runners.

The resulting SRER estimates depend to a large extent on the methodology chosen. It is worth keeping in mind that the FRER approach is comparable to the medium-run methodologies working with the macroeconomic specification of real exchan-

3) Barrell et al. (2002) describes the underlying macroeconomic models estimated for the accession economies on panel data. 
ge rates ${ }^{4)}$ (Table 1). These normative-target based estimates originating in the work of Williamson (1994), search for a medium-term equilibrium that is unobservable from the actual data. According to this approach, the real exchange rate can be driven by notional current account or external debt targets. These targets often reflect the general wisdom about levels of external debts and current account deficits that are sustainable. Recently, the threshold values may also reflect the increased likelihood of an exchange rate crisis. The medium-term SRERs are consistent with internal and external balance of the economy, but do not necessarily reflect equilibrium on all asset markets, since some markets do not clear in the medium run due to various adjustment costs. As a result, stock variables, such as NFAs and the stock of $F D I$, are only converging to their long-term equilibrium levels. That is why their values can only be assessed in terms of sustainability, not in terms of equilibria.

The short-run and medium-run approaches typically find different currency misalignments from the medium-run approaches. The short-run empirical approaches find smaller currency misalignments than the medium-term approaches, as they assume that the real exchange rate can be directly observed to return to its equilibrium value. They estimate deviations of the real exchange rate from short-run equilibrium, which is mainly determined by the financial markets. SRERs working with the long-term horizon typically estimate different signs of currency misalignment than the medium-term SRERs. They are rooted in general equilibrium theory and therefore show the total impact of real convergence on real exchange rates in the long run. However, dynamic general equilibrium models, which usually underline long-term SRERs, cannot be used to compute levels of equilibrium real exchange rates because they work with deviations. A comparison of the actual empirical results related to the newcomers, which is a part of our consistency check, is provided in the concluding section of this paper.

Table 1

Methodologies for Computing SRERs

\begin{tabular}{|l|l|l|l|}
\hline $\begin{array}{l}\text { Horizon } \\
\text { Role of model }\end{array}$ & Short-term horizon & Medium-term horizon & Long-term horizon \\
\hline $\begin{array}{l}\text { Structural model, } \\
\text { theory assumptions }\end{array}$ & & $\begin{array}{l}\text { FEER } \\
\text { DEER } \\
\text { FRER }\end{array}$ & $\begin{array}{l}\text { NATREX } \\
\text { PPP }\end{array}$ \\
\hline $\begin{array}{l}\text { Empirical estimates, } \\
\text { Reduced forms, panels }\end{array}$ & $\begin{array}{l}\text { NATREX * } \\
\text { BEER }\end{array}$ & & $\begin{array}{l}\text { Large panels } \\
\text { with long-term } \\
\text { fundamentals }\end{array}$ \\
\hline
\end{tabular}

Notes: The alternative SRER concepts are explained in the following studies. Fundamental equilibrium exchange rates (FEER) in Williamson (1994). Desirable equilibrium exchange rates (DEER) in Artis, Taylor (1993). Fundamental real exchange rates (FRER) in Šmídková, Barrell, Holland (2002). Natural real exchange rates (NATREX) in Stein, Allen (1995). Purchasing power parity (PPP) in Williamson (1994). Behavioural equilibrium exchange rates (BEER) in MacDonald (1997). An example of a large-panel approach can be found in Halpern, Wyplosz (1997).

* NATREX can be either estimated from a reduced form of the underlying model or computed directly from this model. In the first case, the results are similar to those of the short-run approaches. Applications of the latter approach are relatively rare. For a recent application, see Detken et al., (2002).

4) Other methodologies work with sector specifications based on relative prices of tradable and nontradable goods. The sector approaches cannot be used for assessing the relative price of the domestic currency vis-à-vis the euro and therefore are not included in our survey. 
The medium-term SRERs are usually computed with the use of larger underlying macro-models. It is quite common to assume that the full employment line is vertical with respect to the real exchange rate and to compute SRERs from the trade equations of the underlying macro-model and from an added identity for the external balance. The underlying model can be also used to produce scenarios for variables exogenous to the trade equations. Due to the different structures of the underlying models, different SRERs give emphasis to different economic fundamentals (Table 2). For example, the role of FDI is accentuated only by the FRER model.

Table 2

Underlying Fundamentals of Medium-Term SRERs

\begin{tabular}{|c|c|c|c|}
\hline $\begin{array}{l}\text { SRER concept } \\
\text { Set of fundamentals }\end{array}$ & FEER & DEER & FRER \\
\hline $\begin{array}{l}\text { Trade factors (terms of } \\
\text { trade, domestic and } \\
\text { foreign demand) }\end{array}$ & $\sqrt{ }$ & $\sqrt{ }$ & $\sqrt{ }$ \\
\hline $\begin{array}{l}\text { International factors } \\
\text { (world interest rate) }\end{array}$ & $\sqrt{ }$ & $\sqrt{ }$ & $\sqrt{ }$ \\
\hline $\begin{array}{l}\text { Internal balance } \\
\text { (assumed vertical } \\
\text { full-employment line) }\end{array}$ & $\sqrt{ }$ & $\sqrt{ }$ & $\sqrt{ }$ \\
\hline $\begin{array}{l}\text { External balance } \\
\text { (CA target, debt } \\
\text { target) }\end{array}$ & $\begin{array}{l}\text { Current account } \\
\text { target }\end{array}$ & $\begin{array}{l}\text { Current account } \\
\text { target }\end{array}$ & External debt target \\
\hline $\begin{array}{l}\text { Convergence factors }{ }^{\star} \text { ) } \\
\text { (factors of real } \\
\text { appreciation) }\end{array}$ & $\begin{array}{l}\text { Sustainable capital } \\
\text { inflows }\end{array}$ & $\begin{array}{l}\text { Sustainable capital } \\
\text { inflows }\end{array}$ & $\begin{array}{l}\text { Stock of } F D I \\
\text { (integration gain) }\end{array}$ \\
\hline $\begin{array}{l}\text { Other policy relevant } \\
\text { factors }\end{array}$ & $x$ & Fiscal policy target & Initial level of debt \\
\hline
\end{tabular}

Notes: *) The so-called "convergence factors" are variables that help to explain why relatively fast real appreciation of exchange rates and current account deficits can be sustainable. Specifically, if a country obtains a significant portion of capital inflows that are evaluated by the financial markets as sustainable, larger current account deficits are possible without increased risks of an exchange-rate crisis. Analogously, an increasing stock of FDI implies that the host country can benefit from the so-called "integration gain" and consequently from a stronger currency without additional costs.

There are two major differences between the FRER concept and other SRERs. The FRER defines the external balance in terms of stocks rather than flows and emphasises the role of $F D I$ as the decisive factor in fundamental-based real exchange rate appreciation. Both characteristics are typical of the former transition economies and are difficult to capture in other models. The FRER employs a less binding definition of the external balance than the other approaches. Consequently, when the FRERs are computed for the newcomers, current account deficits can be relatively high in the pre-euro period, when the catch-up process is likely to be at its fastest. However, temporarily larger deficits are only sustainable for those newcomers which did not inherit an excessive stock of external debt. It is worth noting that the FRER and other SRERs also depend on the international environment. A dramatic 
shock affecting international capital flows changes the path of the SRERs. This feature reflects well the experience of the newcomers, which have already found out how big an effect any international financial turbulence can have on their exchange rates.

\subsection{The FRER Model}

As was said, the underlying model of the FRERs has been developed specifically for the EU-acceding economies. Small macro-models of the Czech Republic, Hungary, Poland and Slovenia have been incorporated into an existing global econometric model, NiGEM. NiGEM is a large-scale quarterly macroeconomic model of the world economy. The model is essentially New-Keynesian in its approach, in that agents are presumed to be forward-looking in some markets, but nominal rigidities slow the process of adjustment to shocks. Linkages between countries take place through trade, through interacting financial markets and through international stocks of assets. By incorporating models of the newcomers into an existing global model, it is ensured that the projections of all variables exogenous to the FRER model are consistent. The role that FDI plays in the process of economic convergence is explicitly defined in the underlying NiGEM framework. FDI improves labour productivity and has a direct improving impact on the trade balance, the so-called "integration gain". In addition, the stock of FDI increases the total share of external trade in GDP. FDI interacts with other variables in the underlying macro-model since the $F D I$ inflow is endogenous to the system increasing with lower relative labour costs and higher credibility of the host country. A theoretical model of FDI-driven real exchange rates shows that one can expect an FRER appreciation after an increase in the stock of $F D I$ or a decrease in the initial stock of debt (see Bulír., Šmídková, 2004).

The FRER model is built around empirically estimated trade equations that relate exports and imports to the real exchange rate, the terms of trade, and domestic and foreign economic activity. In addition, the process of real convergence is explicitly reflected in the trade equations. Exports and imports are influenced directly by the stock of $F D I$, and the integration gain improves the trade balance. Second, current account deficits are not excessively restricted if the external debt is reasonably low. According to the theory, the overall impact of $F D I$ on the trade balance should be an improving one $\left(\beta_{3}<\alpha_{3}\right)$. However, it is important to test this hypothesis on data, since the impact of $F D I$ on the trade balance can differ from country to country and depends on whether the FDI requires large-scale imports of technology and whether this technology is used to produce exported goods. In line with the available empirical work, ${ }^{5}$ ) the FRER model assumes that the stock of FDI (relative to GDP) is a significant driving force of economic convergence in the acceding economies. The higher the stock of $F D I$, the higher the economic integration, which in turn tends to promote trade and to improve the trade balance. Exports are boosted with a higher accumulated stock of FDI. Exports also expand when foreign demand increases, the real exchange rate depreciates or the terms of trade improve. For the sake of simplicity, the real exchange rate is defined in terms of the relative import price in the model. Hence, the relative price of exports is expressed by the real exchange rate and the terms of trade.

5) Holland and Pain (1998) study the determinants and impact of $F D I$ in Central and Eastern Europe. 


$$
X=\alpha_{0} \cdot\left(\frac{E \cdot P m}{P}\right)^{\alpha_{1}}\left(\frac{P X}{P m}\right)^{\alpha_{1}} \cdot S^{\alpha_{2}} \cdot F D I S^{\alpha_{3}}
$$

where $X$ is exports (index), $E$ is the (dollar) nominal exchange rate, $P m$ is the effective price of imports, $P$ is the domestic consumer price level, $P X$ is the effective price of exports, $S$ is foreign demand, and FDIS is the stock of $F D I$ in real terms with respect to GDP. All parameters have positive values.

Imports expand when domestic economic activity increases or the real exchange rate appreciates. Similarly to exports, imports increase with higher accumulated stock of $F D I$, but to a smaller extent owing to the integration gain.

$$
M=\beta_{0}\left(\frac{E \cdot P m}{P}\right)^{\beta_{1}} \cdot Y^{\beta_{2}} \cdot F D I S^{\beta_{3}}
$$

where $M$ is imports (index), $E$ is the (dollar) nominal exchange rate, $P m$ is the effective price of imports, $P$ is the domestic consumer price level, $Y$ is domestic output, and FDIS is the stock of $F D I$ in real terms with respect to GDP. Parameters have positive values (only $\beta_{1}<0$ ) and $\beta_{3}<\alpha_{3}$.

The FRER model works with the assumption that there is a certain path for external debt that is sustainable for a given economy and that this path can be approximated by considering the initial stock of debt and the so-called "debt target" for the end of the simulation period. The debt target specifies which debt-to-GDP ratio is sustainable for the economy in the medium run. Since it is not possible to determine the optimal level of external debt within the FRER model, the definition of external balance should be viewed as a normative concept. For example, one can assume that the newcomers do not wish to exceed the safety limits announced by international financial analysts, in order to avoid any costly turbulence of their currencies. ${ }^{6)}$

$$
D^{\star}=\delta\left[D_{0}, D_{T}\right]
$$

where $D^{*}$ is the sustainable path of net external debt (in the domestic currency, in real terms, with respect to GDP). The function $\delta$ extrapolates between the initial level of external debt $D_{0}$, given by the data, and the debt target for the end of the simulation period $D_{T}$.

The model is closed with the following identity that defines the current account balance as the sum of the trade balance and the balance of income. The resulting current account deficit increases the external debt one to one.

$$
M-X+r . D^{\star} \cdot Y=D^{\star} \cdot Y-D_{-1}{ }^{*} \cdot Y_{-1}
$$

where $r$ is the real interest rate abroad.

The FRER path is obtained by solving equations (1) - (4) for a selected simulation period. Given the assumed interactions of domestic trade with the international environment and the scenarios for exogenous variables, the FRERs reflect the following economic fundamentals: the terms of trade, world interest rates, domestic and foreign activity, the stock of FDI and the initial level of (net) external debt. In addition, the FRERs ensure that the constraint on external debt, given by the debt target, is met at the end of the simulation period.

6) The importance of not exceeding the safety limits was confirmed by several experiences of acceding countries. For example, see Šmídková et al. (1998) for an analysis of the Czech experience with the 1997 koruna turbulence. 


$$
\begin{aligned}
& \left\{M \cdot \beta_{0} \cdot(F R E R)^{\beta_{1}} \cdot Y^{\beta_{2}} \cdot F D I S^{\beta_{3}}-X \cdot \alpha_{0} \cdot(F R E R)^{\alpha_{3}} \cdot\left(\frac{P X}{P m}\right)^{\alpha_{1}} \cdot S^{\alpha_{2}} \cdot F D I S^{\alpha_{3}}\right\}= \\
& =(1-r) \cdot D^{*} \cdot Y-D_{-1}{ }^{*} \cdot Y_{-1}
\end{aligned}
$$

where FRER is the fundamental real exchange rate, $\bar{M}$ is the volume of real imports in the base year and $\bar{X}$ is the volume of real exports in the base year.

\section{Computations}

The FRER model is calibrated on the results of previous empirical work on the newcomers. We add a new country-specific definition of external balance to improve the first-generation FRER model. Then a baseline path for the FRER is computed and the so-called "FRER corridors" are derived from sensitivity tests. The corridors reflect the uncertainty relating to the baseline computations. Afterwards, two indicators are constructed for each country. First, an indicator of currency misalignment sends a warning signal if the observed real exchange rate deviates from the $F R E R$ corridor. Second, a sustainability chart compares the FRER corridor with the so-called "stability" corridor. If the two corridors do not overlap in the medium run, inflation and exchange rate stability might be difficult to sustain simultaneously in the forthcoming period. Surprisingly, this issue has not been addressed in previous research.

\subsection{Model Calibration and Baseline Computation}

The parameters of the FRER model have been calibrated on the results of previous empirical work. ${ }^{7)}$ Specifically, the long-term parts of the trade equations, estimated from panel data that form trade blocs in the macro-econometric models of the acceding economies in NiGEM, have been taken into account (Table 3). The estimates of the trade elasticities with respect to FDI are comparable to the estimates for Ireland and estimates for the UK, Germany, France, Sweden and the Netherlands, ${ }^{8)}$ while the estimated elasticities of exports with respect to the real exchange rate are somewhat higher for the newcomers. According to the estimates, the integration gain is ensured by FDI inflows, which improve the trade balance. The elasticities of exports and imports with respect to foreign demand and domestic output respectively have been set at one in order to respect the structure of NiGEM. ${ }^{9)}$ The data panel included all four newcomers. We then apply the same parameters to the group of front runners in order to ask what kind of real exchange rate performance would one expect at the time of their entry into the ERM II, assuming that an identical macroeconomic framework was applied to them. ${ }^{10}$

7) The macro-econometric models are described in Barrell et al. (2002). The estimates of the trade equations are explained in Šmídková, Barrell, Holland (2002).

8) See Barrell, te Velde (2000) and Pain, Wakelin (1998) for a comparison.

9) If estimated empirically, these two elasticities can be higher than one and of different magnitude. For example, the values of Czech trade income elasticities are usually reported to be higher than one, with the export elasticity bigger than the import one. Although the imposed values may depart from the typical empirical results, this is the cost we pay for keeping the model consistent with NiGEM. Moreover, the estimated income elasticities would probably be smaller and of a more similar magnitude if the FDI variable was included in the empirical equation. Also, the FRER corridors reflect the size of equation errors, and hence the outcome of the analysis should not be affected by deviations in a single parameter.

10) A similar approach, albeit applied within a different modelling technique, is suggested in MaesoFernandez, Osbat, Schnatz (2004). 
Table 3

Model Calibration

\begin{tabular}{|l|l|c|}
\hline & Parameter & Value \\
\hline$\alpha 1$ & Export elasticity to real exchange rate & 3.15 \\
\hline$\alpha 2$ & Export elasticity to foreign demand & $1.00^{*}$ \\
\hline$\alpha 3$ & Export elasticity to stock of $F D I$ & 0.70 \\
\hline$\beta 1$ & Import elasticity to real exchange rate & -0.62 \\
\hline$\beta 2$ & Import elasticity to domestic output & $1.00^{*}$ \\
\hline$\beta 3$ & Import elasticity to stock of $F D I$ & 0.24 \\
\hline
\end{tabular}

Note: Parameters are taken from Šmídková, Barrel, Holland (2002). Parameter values labelled with (*) were imposed during the estimations.

The first-generation FRER model (Šmídková, Barrell, Holland, 2002) worked with an assumption that the targeted external debt should equal 60 per cent of GDP in each country. This value corresponded to the safety limit often quoted by private financial institutions. Ades, Kaune (1997) illustrate that a safety limit for the current account deficit was often used by foreign investors to evaluate their investment positions. The safety limit was usually set by a rule of thumb, typically equal to 4 per cent of GDP. Analogously, a rule of thumb of between 50 and 60 per cent of GDP was developed for external debt. ${ }^{11)}$ In this paper, we try to reflect more recent findings suggesting that the rule of thumb may not be suitable for all emerging economies. Specifically, IMF (2002) provides empirical evidence that when debt crises or corrections occur, the external debt ratio is typically below $50-60$ per cent of GDP and that sustainable levels of debt depend on country-specific characteristics (Table 4). Specifically, the higher the export share in GDP is, the higher the threshold triggering a crisis can be. One should note that the safety limit in this context has a different interpretation from the previous version of the FRER model. ${ }^{12)}$ In order to reflect these findings, the FRER model in this paper works with a country-specific definition of external balance. We use the same assumptions for our group of front runners, although it should be kept in mind that the financial markets may apply more generous safety limits once the euro is adopted. ${ }^{13)}$ Since the post-adoption experience of the front runners is not the subject of this study, we leave this question open for further research.

For each country, the FRERs are computed by solving the model using the Winsolve simulation package (Newton method). ${ }^{14)}$ The solution period runs from 1992

11) Both safety limits are derived in a relatively standard framework that makes assumptions about the potential growth of the economy and equilibrium real interest rates and derives the ratio of debt to GDP and the current account and trade balance to GDP in the steady state.

12) Unlike the previously used rules of thumb, these findings are not based on steady state analysis. They are based on cross-country empirical estimates aimed at finding out which factors increase the likelihood of a currency crisis and where the thresholds in the values of these factors that increase the probability significantly lie. Hence, the interpretation of the safety limit is different in this case. It is not the value that does not stabilise with respect to GDP, but the value that increases the likelihood of a crisis.

13) We would like to thank the participants of the ECB seminar for pointing out that there could be a shift in the safety limits after euro adoption.

14) For more information on the Winsolve package, see http://www.econ.surrey.ac.uk/winsolve/. 
Table 4

External Debt Targets

\begin{tabular}{|l|c|c|}
\hline & S\&B\&H & IMF 2002 \\
\hline Benchmark & 60 & $50-60$ \\
\hline Czech Republic & \multirow{2}{*}{$\begin{array}{c}\text { Benchmark applied as } \\
\text { Hungary }\end{array}$} & $65(X / Y>40)$ \\
\cline { 1 - 1 } Poland & & $65(X / Y>40)$ \\
\cline { 1 - 1 } Slovenia & & $53(X / Y>30)$ \\
Greece & $X$ & $65(X / Y>40)$ \\
\hline Portugal & $X$ & $53(X / Y>30)$ \\
\hline Spain & $X$ & $53(X / Y>30)$ \\
\hline
\end{tabular}

Note: Debt targets are defined in per cent of GDP. Targets used for the $1^{\text {st }}$ generation $F R E R(S \& B \& H)$ are described in Šmídková, Barrell, Holland (2002). Targets used for the $2^{\text {nd }}$ generation FRER (IMF, 2002) have been derived from the estimates presented in the IMF study (IMF, 2002). $X / Y$ is the ratio of exports to GDP, which indicates the openness of the economy and the capacity of the economy to repay debts.

to 2022, when external debts converge to their targeted values. Off-sample projections of both domestic and external variables representing the international context are produced within the NiGEM framework. ${ }^{15)}$ This is possible because - as was said - all the analyzed countries are represented with their own country models. The consistent framework ensures that domestic demand, aggregate supply and the external sector are linked together in the underlying models through the wage-price system, wealth and competitiveness.

We present our results in two different time spans. The first time span (1995 2010) relates to the newcomers. The FRERs are computed both in-sample (1995:Q1 - 2003:Q4) and off-sample (2004:Q1 - 2010:Q4). In this time span, the newcomers finish their preparations for EU entry and plan to introduce the ERM II, and later on, adopt the euro. The second time span (1992 - 2003) tracks the experience of the front runners with the preparations for euro adoption. The Portuguese escudo and Spanish peseta entered the ERM II in 1996, whereas the Greek drachma joined in 1998. Following the two-year period of nominal-convergence assessments, these countries adopted the euro in 1999 and 2001, respectively. The last three years of the $1992-2003$ period illustrate the post-adoption experience of the front runners. In the case of the front runners, all the computations are done in-sample.

\subsection{The FRER Corridors and the Stability Corridors}

As with the other indicators, the computations of currency misalignment and sustainability charts are useful only if they include information about the robustness of the results. We performed extensive sensitivity tests in order to compute confidence bands for both the in-sample and off-sample (projection) periods (Table 5). The in-sample confidence bands are obtained from the estimation errors of the tra-

15) Information about the National Institute Global Econometric Model (NiGEM) can be found at http:/ /www.niesr.ac.uk/models/nigem/nigem.htm. 
de equations. The off-sample confidence bands include in addition an approximation of the uncertainty relating to the forecast of variables exogenous to the FRER model (historical standard errors) and an approximation of the uncertainty about the targeted value of external debt (authors' computation). When approximating the debt target, we take into account empirical findings about the threshold values triggering a crisis that were summarised above. These findings suggest that the uncertainty relating to the debt target may be around 10 per cent of GDP. ${ }^{16)}$ The resulting confidence bands relating to the FRER computations are of a similar order compared to other studies on SRERs. ${ }^{17)}$ A further robustness check is presented in the concluding section, where our results are compared to other recent studies.

Table 5

Sensitivity Analysis: Confidence Bands

\begin{tabular}{|c|c|c|}
\hline FRER Component & Sources of uncertainty & \\
\hline & In-sample computations & Off-sample computations \\
\hline World interest rate & Non $(O D)$ & $1 \mathrm{pp}(A V)$ \\
\hline Domestic output & Non $(O D)$ & $1 \%(A V)$ \\
\hline Import equation & \multicolumn{2}{|c|}{ Country specific (SE) } \\
\hline Terms of trade & Non $(O D)$ & $2 \%(A V)$ \\
\hline Export equation & \multicolumn{2}{|c|}{ Country specific (SE) } \\
\hline Foreign demand & Non $(O D)$ & $5 \%(A V)$ \\
\hline Stock of $F D I$ ( $\%$ of GDP) & Non $(O D)$ & $10 \mathrm{pp}(A V)$ \\
\hline Debt target & \multicolumn{2}{|c|}{ $\pm 5 \%$ of GDP (according to the benchmark estimates) } \\
\hline
\end{tabular}

Note: If the data are observable $(O D)$, there is no additional uncertainty attached to the model uncertainty resulting from exogenous variables. For the off-sample projections, the average volatility of the data series (over the period $1992-2003$ across countries) is taken to calibrate the scale of uncertainty ( $A \mathrm{~V}$ ). For the whole simulation period, the country-specific uncertainty relating to the estimations is considered based on the standard errors of the estimated trade equations $(S E)$. The interval of the benchmark estimates of sustainable debt levels is calibrated according to the findings presented in Table 4.

Indicators of currency misalignment are constructed by comparing the observed values of the real exchange rates with the computed FRERs and with the in-sample confidence bands. Sustainability charts compare the FRER corridors with the stability corridors. The FRER corridors show the confidence bands around the baseline values of the FRERs, in-sample bands for the front runners and both in- and off-sample bands for the newcomers. The widths of these bands differ according to the specific features of the individual economies. For example, the FRER corridor for Hungary is typically wider than the corridors of the other newcomers owing to larger estimation errors in the panel-based trade equations.

16) Šmídková, Barrel, Holland (2002) show that the FRERs are not over-sensitive to the definition of the debt target. Hence, a relatively large uncertainty relating to the sustainable debt path does not imply that it is impossible to compute FRERs.

17) Williamson (1994) and Bayoumi, Clark, Symansky, Taylor (1994) report similar estimates of the uncertainties pertaining to computations of equilibrium real exchange rates. Detken, Dieppe, Henry, Marin, Smets (2002) estimate the uncertainty specifically for the equilibrium real exchange rates of the euro at around 20 per cent. 
The stability corridors examine the sustainability of meeting the Maastricht convergence criteria for inflation and the exchange rate simultaneously. Due to the various interpretations of exchange rate stability, we compute two alternative stability corridors for each acceding country. ${ }^{18)}$ In both cases, the stability corridors assume that the exchange rate vis-à-vis the euro is fixed in 2004 in the newcomers. For the front runners, the dates of actual ERM II entry are known, and hence they can be used for computing the stability corridors. The third alternative definition of the stability corridor applies to the post-adoption period. After adopting the euro, not only do the front runners keep their nominal exchange rates fixed vis-à-vis euro - in addition, they should have inflation rates close to the ECB definition of price stability. ${ }^{19)}$ Otherwise, there is an increased risk of various imbalances emerging in the front runners' economies. The width of the third type of stability corridor reflects the uncertainty surrounding the definition of price stability.

\section{Results}

We summarise the empirical results in three subsections. First, we show the measure of currency misalignment for the Czech koruna, Hungarian forint, Polish zloty and Slovenian tolar prior to the EU entry. Second, we present a forward-looking measure of real exchange rate stability for the four newcomers in the run-up to euro adoption. Third, we provide the same measure of real exchange rate stability for the three front runners, Greece, Portugal and Spain, computed ex post for the period prior to their entry into the euro area. Our findings suggest that if all four newcomers as a group were to have entered the ERM II in 2004 and to have met the Maastricht criteria as well, it might have done them more harm than good. All currencies but the tolar seemed to be overvalued, and the estimated speed of FRER appreciation was not high enough to compensate for that currency misalignment in the short run. Hence, the currencies were likely to have remained overvalued for a considerable period of time if the countries had raced to the euro without considering their specific conditions. If the central parity had been specified at a weaker-than-market rate in order to prevent the problems of an overvalued currency, meeting the inflation criterion might not have been feasible. The estimated speed of FRER appreciation signals that a corrective revaluation of the central parity might have been required to avoid inflationary consequences of the initial devaluation. Our empirical findings are consistent with a recently published policy suggestion that the newcomers might benefit from maintaining their pre-EU exchange rate regimes for some time after EU entry (see Backé et al., 2004).

The front runners' smooth sailing into the euro area should not be taken as an assurance of a similar performance by the newcomers. We are sceptical, both because of the initial currency misalignment and because the prospects of real exchan-

18) ERM2 permits nominal exchange rate fluctuations within a \pm 15 per cent band. This requirement differs from the exchange rate stability criterion sometimes quoted, which requires "observation of normal fluctuation margins provided by the exchange-rate mechanism of the European Monetary System, for at least two years, without devaluing against the currency of any other Member State" (Article 121(I) of the Maastricht Treaty). Specifically, the criterion was set as fluctuation margins of $\pm 2 \frac{1}{4}$ per cent against the median currency.

19) However, five years after euro adoption, not all members of the euro area have managed to maintain inflation at that desired level. Angeloni and Ehrmann (2004) discuss the problem of prevailing inflation differentials within the euro area. They find that among several potential causes of inflation differentials, inflation persistence plays a dominant role, other causes being differences in monetary transmission or asymmetric shocks. 
ge rate stability prior to euro adoption were more favourable in the front runners' group. Also, the front runners entered the ERM II during periods of relative tranquillity in international financial markets. The newcomers may not be as lucky.

Although the real exchange rate takes centre stage in the FRER model, the indications of currency misalignment should not be viewed as a direct consequence of exchange rate policy alone. Differences between the FRERs and observed values of real exchange rates are often outcomes of a combination of various events, some of them domestic and some international. Analogously, rescue remedies should not be expected from changes in exchange rate strategy itself. For example, massive FDI inflows attracted by credible domestic economic reforms or permanent changes in the terms of trade may be sufficient to solve the problems. For that reason, we suggest using the FRER model in order to produce indicators rather than using it to drive exchange rate policies. The latter approach has also been debated occasionally. Specifically, the issue of whether the desired exchange rate system should ensure internal and external stability, or whether policies should be designed to create the internal and external conditions under which the desired equilibrium naturally emerges, has been discussed (see Williamson, 1994).

\subsection{Currency Misalignment prior to the EU Entry}

According to the FRER model, three acceding currencies were significantly overvalued prior to the EU entry (Figure 3). Fixing the euro conversion rates at the 2004

Figure 3

Overvaluation of Currencies in 2003: The Newcomers
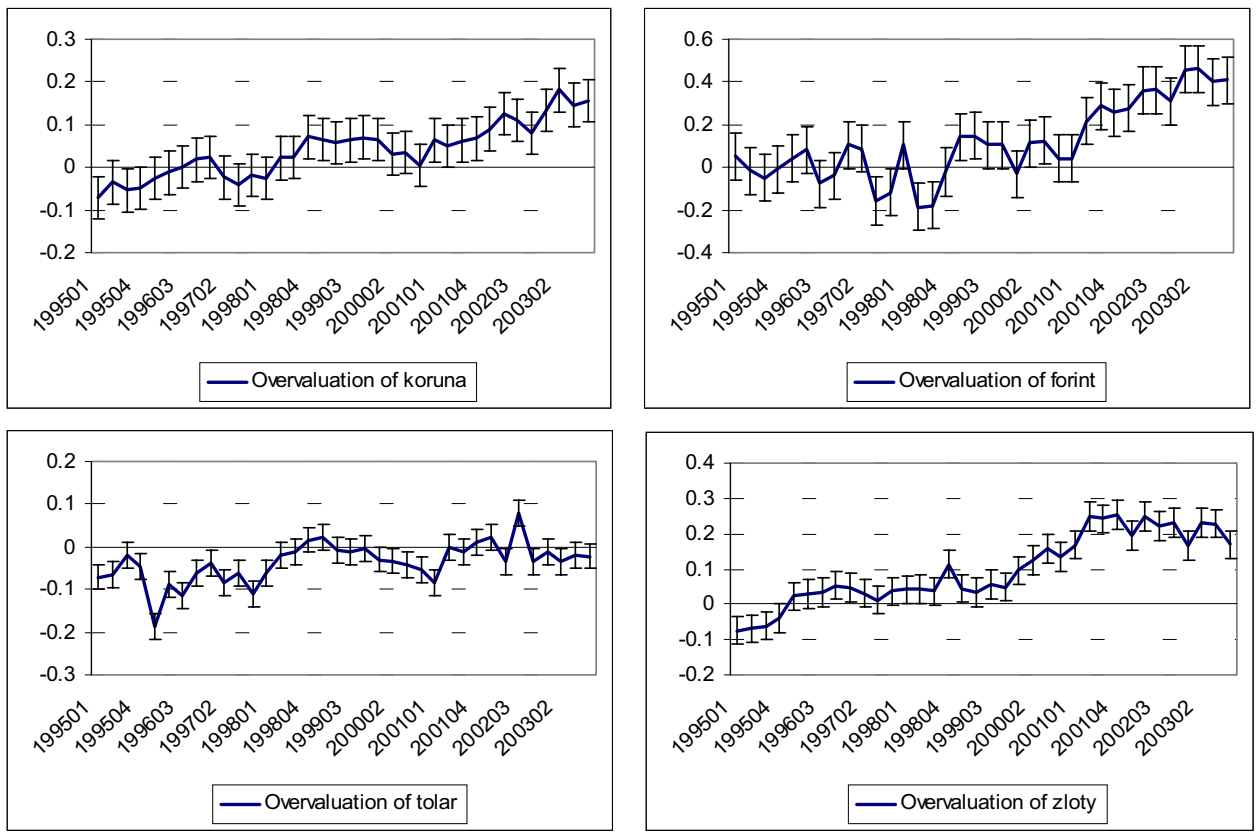

Note: The computed real effective exchange rate misalignments are reported as index values. For example, a value of 0.1 implies an overvaluation of 10 per cent. The attached confidence bands reflect the underlying uncertainty of the computations. 
exchange rates would have posed a major problem for the forint, zloty and koruna (in that order), but not for the tolar. These rates would not have corresponded to the economic fundamentals captured by the FRER model and subsequent external imbalance could have disrupted nominal convergence. On average, economic fundamentals explain about 60 per cent of the real appreciation during the last decade. The remaining part reflects perhaps too optimistic expectations about the speed of real convergence of the newcomers, the temporary impact of privatisation inflows and the psychological effect of the forthcoming EU enlargement, which determined short-term equilibria on financial markets. The impact of the financial markets on currency misalignments was especially evident when monetary policy strategies were changed and the financial markets had their say after periods of passively watching the exchange rates fixed by the domestic authorities. The koruna was allowed to float in 1997, the zloty in 1999 and the forint in 2001. Interestingly, Slovenia was the only acceding country in our sample that did not rely on exchange rate stabilisation in the period of economic transition. In 2003, partial corrections of the previous excessive real appreciation trend took place and real exchange rates better reflected the medium-term prospects of the newcomers.

The Czech koruna went through a period of minor undervaluation during 1995 1996. After the currency turbulence in 1997 - 1998, the real exchange rate appreciated sharply in 1999. The resulting overvaluation of 5 per cent increased to about 15 per cent in 2003. In 2003, the misalignment was corrected to some extent by a nominal depreciation, but low inflation kept the koruna overvalued. The computed confidence band is narrow at \pm 5 per cent. The Hungarian forint avoided overvaluation until 2000. During 2001 - 2002, a sharp real appreciation led to a massive currency misalignment of some 40 per cent, which was subsequently corrected to some extent in late 2003 . The confidence band is wide at \pm 11 per cent. The Polish zloty was marginally overvalued for several years until early 2000. Subsequently, a gradual real appreciation led to a misalignment of some $15-25$ per cent in 2002 . In 2003 , the zloty started depreciating and the misalignment was gradually reduced to 17 per cent. The confidence band is narrow at \pm 4 per cent. The Slovenian tolar seemed to be in line with economic fundamentals in 2003 after a protracted period of real undervaluation. The confidence band is the narrowest at \pm 3 per cent.

\subsection{Sustainability of Nominal Convergence after the EU Entry}

In the period $2004-2010$, the computed FRERs show a continuing tendency of real appreciation in all four newcomers as a result of progressing real convergence (Figure 4). According to the constructed sustainability charts, the nominal convergence required by the Maastricht criteria and theERM II may prevent the currencies of the newcomers from converging towards their medium-term equilibrium values. Due to potential external imbalances, it may not be feasible to meet the official criteria of nominal convergence soon after the EU entry without increased risks of unsustainable developments in the medium run. It is worth noting that although our sample of newcomers is relatively small, the countries analyzed do not face identical problems. On the one hand, the forint's FRER is likely to remain well above the broader \pm 15 per cent stability corridor. Assuming that exchange rate and monetary policies keep the real exchange rate within the stability corridor, the depreciation required to reach external balance is not a viable option. On the other hand, the tolar may need a modest revaluation towards the end of this decade.

The Czech koruna is likely to remain overvalued after the EU entry if the nominal exchange rate and inflation develop in line with the nominal convergence criteria. The real appreciation that is in line with economic fundamentals will not be fast 
Figure 4

Sustainability Charts: The Newcomers
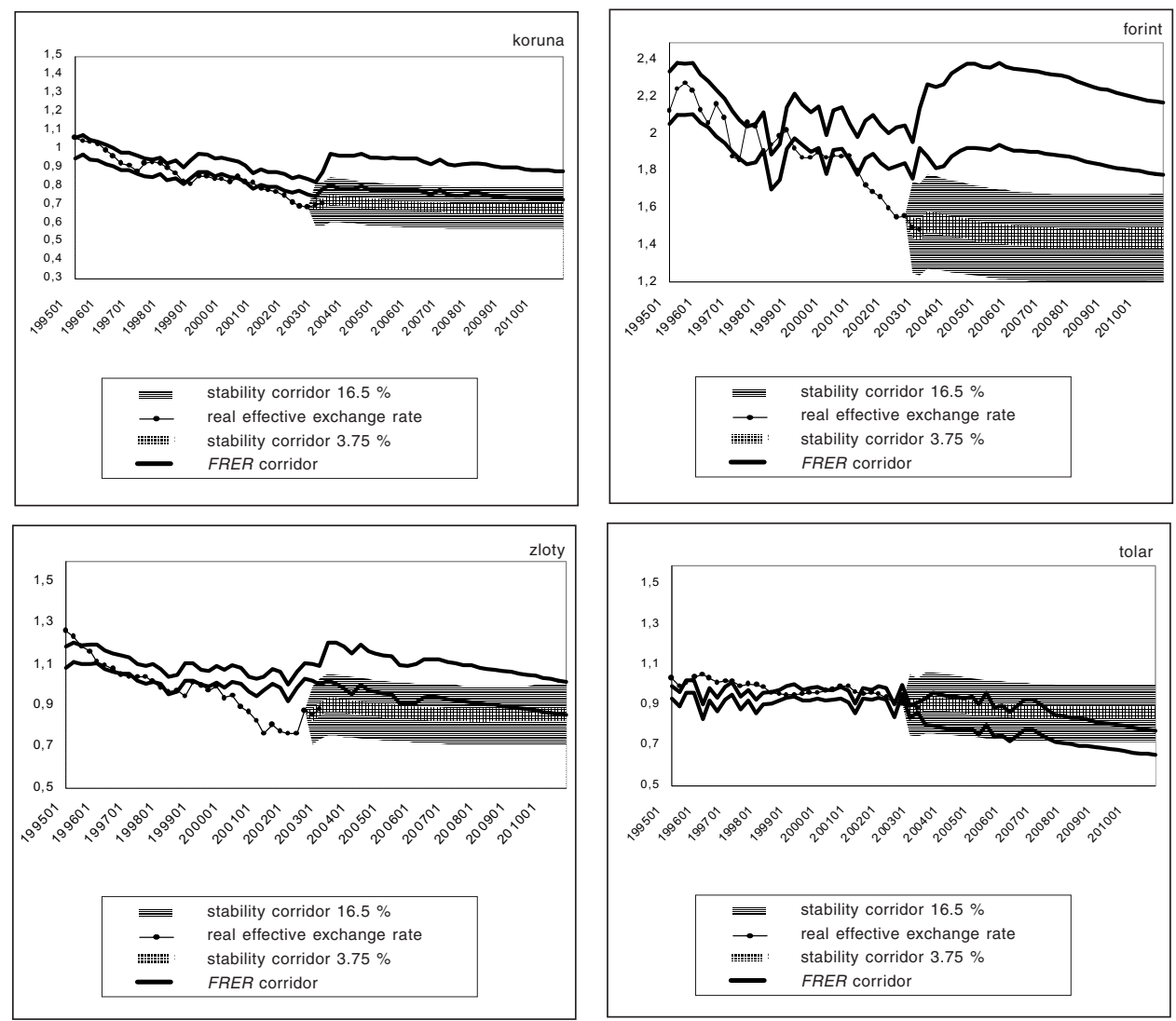

Note: The 2004:Q1 value of the koruna's real effective exchange rate has been used as a starting point for the computations of the stability corridors. The stability corridors illustrate which real exchange rate path is compatible with the nominal convergence criteria, given that the nominal exchange rate can fluctuate within either a narrow band $(2.25 \%)$ or a broader band $(15 \%)$. The FRER corridor reflects the baseline FRER and the estimated uncertainty.

enough to compensate for the 2003 overvaluation. Only around 2007 the real exchange rate could restore external balance, if the koruna can fluctuate within the \pm 15 per cent band. The Hungarian forint is far away from its medium-term equilibrium. During 2004 - 2010 nominal convergence and external balance are found to be incompatible. The Polish zloty follows a similar pattern to the koruna during $2004-$ 2010 , only in a shorter time span. In the short-term, the nominal convergence criteria will be too restrictive to bring the Polish currency into line with external balance. Around 2007, the zloty can fluctuate within the \pm 2.25 per cent band and be compatible with external balance. This finding implies that nominal convergence may be sustainable sooner than in the Czech case. The Slovenian tolar may need a revaluation of up to 10 per cent around 2010. During $2004-2010$, nominal convergence appears sustainable with respect to external balance in the Slovenian case. 


\subsection{Experience of the Front runners}

We compare the FRERs of the four newcomers computed for $2004-2010$ to those of the three front runners (Greece, Portugal and Spain) computed for 1992 2003. The $1992-2003$ period covers their seven-year experience of preparing for the euro as well as a brief post-adoption period. If the newcomers adhere to their pre-announced euro adoption schedules, they have less than seven years to prepare for the euro after the EU entry. We can see from the front runners' experience whether their smooth sailing into the euro area can be taken as an assurance of a similar performance by the newcomers. We find that, first, the front runners started their testing period with fundamentally correct parities vis-à-vis the euro, and, second, prior to euro adoption their ERM II parities seemed sustainable for the period ahead (Figure 5).

Figure 5

\section{Sustainability Charts: The Front Runners}
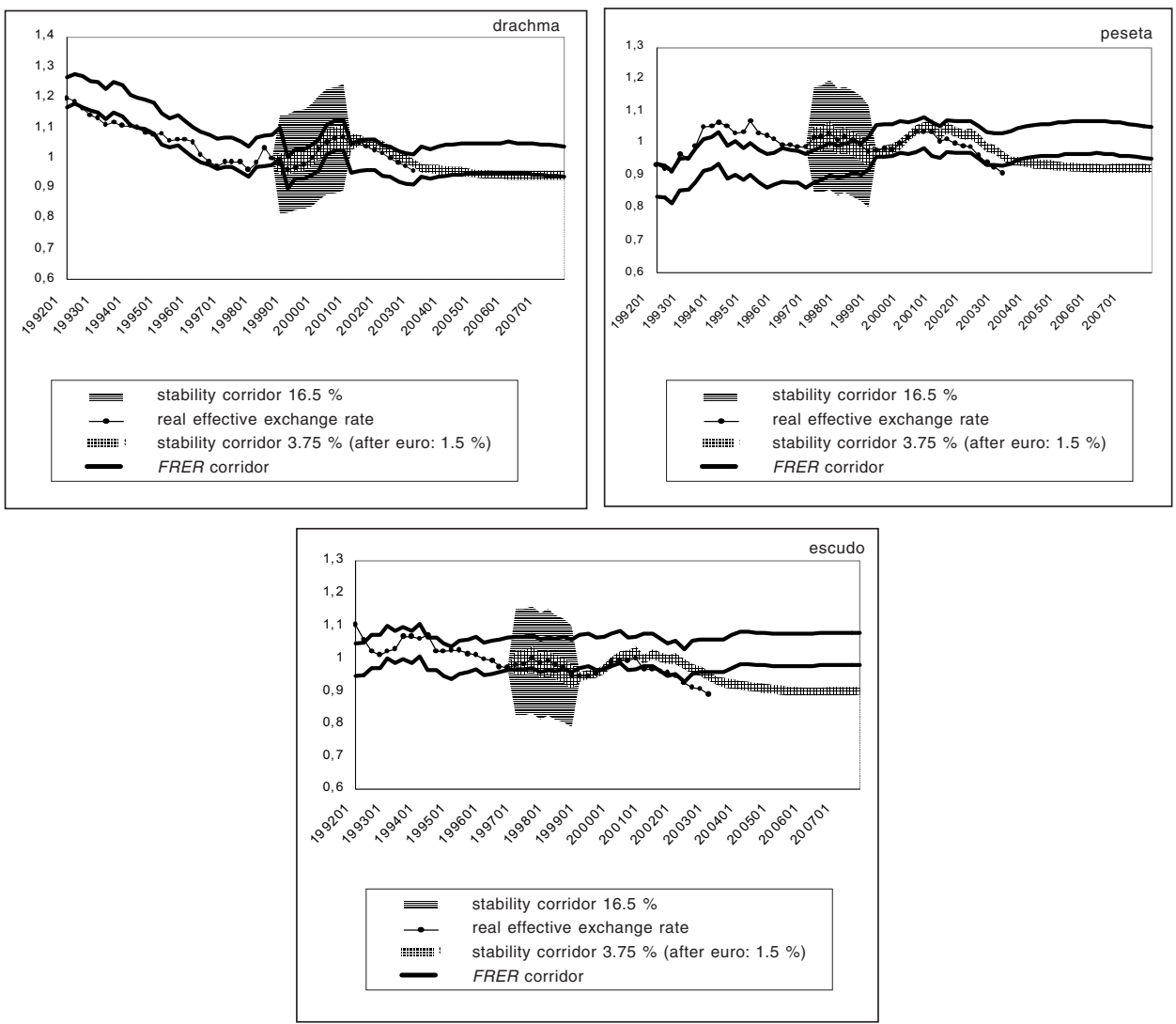

Note: Prior to euro adoption, the stability corridors illustrate which real exchange rate path is compatible with the nominal convergence criteria, given that the nominal exchange rate can fluctuate within either a narrow band $( \pm 2.25$ per cent) or a broader band ( +15 per cent). After euro adoption, the stability corridors illustrate which real exchange rate path is compatible with the ECB definition of price stability. The FRER corridor reflects the baseline FRER and the estimated uncertainty. 
If anything, the peseta was slightly undervalued in $1993-1998$. Following euro adoption, the real exchange rate remained broadly in line with Spanish economic fundamentals until 2003. However, the real appreciation was stronger than would have been required by the Maastricht inflation criterion. The drachma was in line with economic fundamentals in the $1992-2003$ period according to the FRER model. The escudo remained in line with economic fundamentals until 1999, although it was closer to overvaluation than the drachma. According to the FRER model, the euro was some by $10-20$ per cent stronger in real terms for Spain and Portugal at the end of 2003.

\section{Concluding Remarks}

The computed fundamental real exchange rates for the newcomers and front runners suggest that three of the analyzed newcomers (the Czech Republic, Hungary and Poland) would be likely to experience difficulties during their stay in the ERM II if they were to introduce it too soon after the EU entry. The front runners' smooth sailing into the euro area should not be taken as an assurance of a similar performance by the newcomers. The following four conclusions are worth highlighting.

First, we find that all the analyzed newcomers' currencies except the Slovenian tolar were overvalued prior to the EU entry. This finding corresponds to the results of other studies that have recently estimated the currency misalignments of the newcomers and used comparable, medium-term, methodologies (Table 6). ${ }^{20)}$ At first

Table 6

\section{Recent Estimates of Currency Misalignment}

\begin{tabular}{|c|c|c|c|c|}
\hline $\begin{array}{l}\text { Country } \\
\text { Outcome }\end{array}$ & Czech Republic & Hungary & Poland & Slovenia \\
\hline $\begin{array}{l}\text { Overvalued by } \\
\text { more than } 10 \%\end{array}$ & $\mathrm{~S} \& \mathrm{~B}(F R E R)$ & $\begin{array}{l}\text { S\&B }(F R E R) \\
\text { S\&B\&H }(F R E R) \\
\text { C (FRER) }\end{array}$ & $\begin{array}{l}\text { S\&B }(F R E R) \\
\text { S\&B\&H }(F R E R)\end{array}$ & \\
\hline $\begin{array}{l}\text { Overvalued by } \\
\text { less than } 10 \%\end{array}$ & $\begin{array}{l}\text { C\&C (FRER) } \\
\text { S\&B\&H }(F R E R)\end{array}$ & $\begin{array}{l}\mathrm{C} \& \mathrm{C}(F R E R) \\
\mathrm{C}(B E E R)^{\star *} \\
\mathrm{C}(\text { NATREX) })^{\star *}\end{array}$ & $\begin{array}{l}\mathrm{C} \& \mathrm{C}(F R E R) \\
\mathrm{R}(F R E R)\end{array}$ & $\mathrm{C} \& \mathrm{C}(F R E R)$ \\
\hline $\begin{array}{l}\text { In line with } \\
\text { fundamentals }\end{array}$ & $\mathrm{F} \& \mathrm{~K}(B E E R)^{* *}$ & & & $\begin{array}{l}\text { S\&B\&H (FRER) } \\
\text { G\&K (FRER) }\end{array}$ \\
\hline $\begin{array}{l}\text { Undervalued by } \\
\text { less than } 10 \%\end{array}$ & $\begin{array}{l}\text { F\&K }(N A T R E X \\
\text { reduced form })^{\star *}\end{array}$ & & & $\mathrm{~S} \& \mathrm{~B}(F R E R)$ \\
\hline $\begin{array}{l}\text { Undervalued by } \\
\text { more than } 10 \%\end{array}$ & $\mathrm{E}(P P P)^{*}$ & $\mathrm{E}(P P P)^{*}$ & $\mathrm{E}(P P P)^{*}$ & $\mathrm{E}(P P P)^{*}$ \\
\hline
\end{tabular}

Notes: This table compares recent estimates of currency misalignment in the newcomers, mostly from 2001 - 2003. Medium-term methodologies have recently been applied, for example, in the following studies: Šmídková, Barrell, Holland, 2002; Coudert and Couharde, 2002; Genorio and Kozernik, 2003; Rubaszek, 2003 and this paper.

*) Long-term methodologies have recently been applied, for example, in Égert, 2003.

$\left.{ }^{\star \star}\right)$ Short-term methodologies have recently been applied, for example, in Csjabók, 2003 and Frait and Komárek, 2001.

20) Interestingly, in a comparable time span, estimates of the equilibrium value of the real effective euro exchange rate (see Detken et al., 2002) suggested a mild undervaluation of the euro. 
sight, a comparison of all the available empirical results related to the real exchange rates of the newcomers gives a somewhat mixed picture. The results may even seem contradictory. However, all studies based on medium-term methodologies gave similar warning signals regarding currency misalignment for the Czech Republic, Hungary and Poland. On the other hand, the long-term approaches (see Égert, 2003) concluded that the national currencies were undervalued prior to the EU entry, since the equilibrium real appreciation would continue for some considerable period of time. The short-term approaches (see Frait, Komárek, 2001; Csjabók, 2003 and Couder, Couharde, 2002) found the real exchange rates of the newcomers to be quite close to their equilibrium values determined by the financial markets.

Once methodological differences are accounted for, the picture about the currency misalignments of the newcomers becomes a bit clearer. This is because the time horizon of the selected methodology plays an important role in computations of equilibrium real exchange rates, since the short-, medium- and long-run equilibria are not identical (see Driver, Westaway, 2003). Short-term methodologies find real exchange rates to be closer to their equilibrium values than medium-term approaches because they search for misalignment from the perspective of the financial markets. The same conclusion sometimes holds for medium-term methodologies that calibrate normative targets in line with observed values of current account deficits. On the contrary, long-term methodologies estimate the scope for further real appreciation after all constraints, including the one imposed by the financial markets on external debt, are removed completely and after the transition towards equilibrium on all goods and asset markets is over. To some extent, the long-term methodologies give results analogous to our sustainability charts. Due to the convergence process, the real exchange rates of the newcomers might not be as stable as they should be according to the nominal convergence criteria.

Secondly, we would like to highlight the issue of ex ante analysis of real exchange rate stability in the run-up to euro adoption, which the empirical literature has not focused on very much to date. Égert (2002b) concluded that real exchange rate volatility is not likely to pose a problem and that accession countries should enter the ERM II as quickly as possible. Šmídková et al. (2002) are much less optimistic, foreseeing volatility related to the underlying fundamentals and real convergence. Forward-looking computation of the FRERs through 2010 indicates that the currencies of the newcomers are unlikely to stay within the stability corridors if real exchange rates converge to their equilibrium levels. Pursuing the convergence criteria too soon after the EU entry may prevent the Czech, Hungarian and Polish economies from maintaining external balance. In contrast, the Slovenian currency may require sizeable revaluation prior to euro adoption. Ex post simulations for those countries that adopted the euro in the late 1990s - Greece, Portugal and Spain - show no currency misalignment at the time of introducing the ERM II. They also show that their real exchange rates followed a more stable path after introducing the ERM II than can be expected in the case of the newcomers.

Our third conclusion relates to differences among the newcomers. Although our sample consists of only four newcomers, we have been able to detect different problems regarding compatibility between the nominal convergence criteria and the underlying economic fundamentals during the forthcoming period. On the one hand, for some countries, currency misalignment may pose a serious problem. On the other hand, other newcomers may succeed with a gradual revaluation strategy. Analogously, forward-looking analysis sends warning signals only to some countries that may not be able to maintain external balance and simultaneously meet the nominal convergence criteria, no matter how softly the exchange rate bands of the ERM II are interpreted. For some newcomers, the actual interpretation of exchange rate 
stability may play an important role, since the softer definition may be in line with economic fundamentals while the strict definition may be incompatible with them.

Fourth, following euro adoption, the convergence problems will not disappear. Should a slowdown of FDI inflows materialise - as observed in the case of the front runners - convergence might decelerate in the newcomers. It would remain to be seen whether domestic investment would be sufficient to pick up the slack. Moreover, it is unclear whether the newcomers will be able to accumulate foreign liabilities at a sufficient speed, given their already relatively high levels of external indebtedness. Their position in this respect is different from that of the front runners, who could afford further external debt accumulation. For the above-mentioned reasons, an early "race to the euro" appears to be a costly competition indeed.

\section{References}

Ades, A., Kaune, F. (1997), A New Measure of Current Account Sustainability for Developing Countries. Goldman-Sachs Emerging Markets Economic Research.

Angeloni, I., Ehrmann, M. (2004), "Euro Area Inflation Differentials." Frankfurt, European Central Bank, mimeo.

Angeloni, I. Dedola, L. (1999), "From the ERM to the Euro: New Evidence on Economic and Policy Convergence among EU Countries." Frankfurt, ECB Working Paper No. 4.

Artis, M. J.,Taylor, M. P. (1993), "DEER Hunting: Misalignment, Debt Accumulation and Desired Equilibrium Exchange Rates." Washington, IMF WP/93/48.

(1995), "The Effect of Misalignment on Desired Equilibrium Exchange Rates: Some Analytical Results," in Bordes, C., Girardin, E., and Mélitz, J., (eds.), European Currency Crises and after. Manchester: Manchester University Press, pp. 123-141.

Artus, J. (1977), "Methods of Assessing the Long-Run Equilibrium Value of an Exchange Rate." Washington, IMF WP/77/124.

Backé, P., Thimann, Ch., Arratibel, O., Calvo-Gonzalez, O. Mehl, A., Nerlich, C. (2004), "The Newcomers' Strategies towards ERM II and the Adoption of the Euro: An Analytical Review." Frankfurt, ECB Occasional Paper No. 10.

Barrell, R., Holland, D., Jakab, Z. M., Kovács, M. A., Šmídková, K., Sepp, U., Čufer, U. (2002), “An Econometric Macro-Model of Transition: Policy Choices in the Pre-Accession Period." Proceedings of AMFET 2001 Conference - Modelling Economies in Transition, Krag (Poland), (Lodz: Absolwent). Barrell, R., te Velde, D. W. (2000), "A Note on Multinationals and Irish Trade." London, NIESR, mimeo.

Barrell, R., Wren-Lewis, S. (1989), "Fundamental Equilibrium Exchange Rates for the G7." London, CEPR Discussion Paper No. 323.

Benáček, .V., Prokop, L., Víšek, J. Á. (2003), "Determining Factors of the Czech Foreign Trade Balance: Structural Issues in Trade Creation." Prague, CNB Working Paper 3/2003.

Borensztein, E., De Gregorio, J., Lee, J. W. (1998), "How Does Foreign Direct Investment Affect Economic Growth?" Journal of International Economics, 45 (1), pp. 115-135.

Borghijs, A., Kuijs, L. (2004), "Exchange Rates in Central Europe: A Blessing or a Curse?" Washington, IMF WP/04/2.

Bulír, A., Šmídková, K. (2004), "Exchange Rates in the New EU Accession Countries: What Have We Learned from the Forerunners?" Prague, Czech National Bank Working Paper No. 10.

Bun, M. et al. (2002), "Has the Euro Increased Trade?"Amsterdam, Tinbergen Institute Discussion Paper TI 2002-108/2.

Bussière, M., Fratzscher, M., Müller, G. J. (2004), "Current Accounts Dynamics in OECD and EU Newcomers - An Intertemporal Approach." Frankfurt, ECB Working Paper No. 311.

Campos, N. F., Kinoshika, Y. (2003), "Why Does FDI Go Where It Goes? New Evidence from the Transition Economies." Washington, IMF WP/03/228.

Csjabók, A. (2003), "The Equilibrium Real Exchange Rate in Hungary: Results from Alternative Approaches." Paper presented at the Research Meeting "Equilibrium Exchange Rates in Accession Countries: Macroeconomic and Methodological Issues." Frankfurt, European Central Bank.

Clark, P., B., Bartolini, L.,Bayoumi, T., Symansky, S. (1994), "Exchange Rates and Economic Fun- 
damentals: A Framework for Analysis." Washington, IMF Occasional Paper No. 115.

Coudert, V., Couharde, C. (2002), "Exchange Rate Regimes and Sustainable Parities for CEECs in the Run-up to EMU Membership." Paris, CEPII Working Paper No. 2002-15.

De Broeck, M., Sløk, T. (2001), "Interpreting Real Exchange Rate Movements in Transition Countries." Washington, IMF WP/01/56.

Detken, C., Dieppe, A., Henry, J., Marin, C., Smets, F. (2002), "Model Uncertainty and the Equilibrium Value of the Real Effective Euro Exchange Rate." Frankfurt, ECB Working Paper No. 160.

Driver, R., Westaway, P. F. (2003), "Concepts of Equilibrium Exchange Rates," London, Bank of England, mimeo.

Edwards, S. (1989), Real Exchange Rates, Devaluation and Adjustment. Cambridge, Massachusetts: MIT Press.

Égert, B. (2002a), "Equilibrium Real Exchange Rates in Central Europe's Transition Economies: How Far Is Heaven?" Paper presented at the European Conference in International Economics and Finance, Heraklion-Crete, Greece, May 17-20.

(2002b), "Estimating the Impact of the Balassa-Samuelson Effect on Inflation and the Real Exchange Rate During the Transition." Economic Systems, 26, pp. 1-16.

(2003), "Assessing Equilibrium Exchange Rates in CEE Newcomers: Can We Have DEER with BEER without FEER? A Critical Survey of the Literature." Wien, National Bank of Austria Focus on Transition No. 2.

Elbadawi, I. A., Soto, R. (1997), "Real Exchange Rates and Macroeconomic Adjustment in SubSaharan Africa and Other Developing Countries," Journal of African Economies, Supplement 6 (3), pp. 74-120.

Feyzioğlu, T. (1997), "Estimating the Equilibrium Real Exchange Rate: An Application to Finland," Washington, IMF WP/97/109.

Flek, V., Marková, L., Podpiera, J. (2003), "Sectoral Productivity and Real Exchange Rate Appreciation: Much Ado about Nothing?" Czech Journal of Economics and Finance, 53, 3-4, pp. 130-153. Frait, J., Komárek, L. (2001), "Real Exchange Rate Trends in Transitional Countries," Warwick, University of Warwick, The Warwick Economic Research Paper No. 596.

Frankel, J., Rose, A. (2002), "An Estimate of the Effect of Common Currencies on Trade and Income," Quarterly Journal of Economics, 117, 2, pp. 437-466.

Genorio, H., Kozernik, D. (2003), "FEER Estimates - Slovenian Case," Frankfurt, European Central Bank Paper presented at the Research Meeting "Equilibrium Exchange Rates in Accession Countries: Macroeconomic and Methodological Issues,".

Halpern, L., Wyplosz, Ch. (1997), "Equilibrium Exchange Rates in Transition Economies," IMF Staff Papers, 44, pp. 430-461.

Holland, D., Pain, N. (1998), "The Diffusion of Innovations in Central and Eastern Europe: A Study of the Determinants and Impact of Foreign Direct Investment." London, NIESR Discussion Paper No. 137.

International Monetary Fund (2002), Assessing Sustainability. Washington: International Monetary Fund.

Isard, P., Faruqee, H., Kincaid, G. R., Fetherston, M. (2001), "Methodology for Current Account and Exchange Rate Assessments." Washington, IMF Occasional Paper No. 209.

Lane, P. R., Milesi-Ferretti, G. M. (2000), "The Transfer Problem Revisited: Net Foreign Assets and Real Exchange Rates." Washington, IMF WP/00/123.

(2002). "External Wealth, the Trade Balance, and the Real Exchan-

ge Rate," European Economic Review, 46, pp. 1049-1071.

Lansbury, M., Pain, N., Šmídková, K. (1996), "Foreign Direct Investment in Central Europe since 1990: An Econometric Study." National Institute Economic Review, 156, pp. 104-114.

Lim, E. G. (2001), "Determinants of, and the Relation between, Foreign Direct Investment and Growth:

A Summary of the Recent Literature." Washington, IMF WP/01/175.

Lipschitz, L., Lane, T., Mourmouras, A. (2002), "Capital Flows to Transition Economies: Master or Servant?" Washington, IMF WP/02/11.

MacDonald, R. (1997), "What Determines Real Exchange Rates? The Long and the Short of It," in MacDonald, R., Stein, J. (eds.), Equilibrium Exchange Rates. Dordrecht, London: Kluwer Academic Publishers.

MacDonald, R., Ricci, L. A (2003), "Estimation of the Equilibrium Real Exchange Rate for South Africa." Washington, IMF WP/03/44. 
Maeso-Fernandez, F., Osbat, Ch., Schnatz, B. (2001), "Determinants of the Euro Real Effective Exchange Rate: A Beer/Peer Approach," Frankfurt, ECB Working Paper No. 85.

(2004), "Towards the Estimation of Equilibrium Exchange Rates for CEE Newcomers: Methodological Issues and a Panel Cointegration Perspective." Frankfurt, ECB Working Paper No. 353.

Mihaljek, D. (2002), "The Balassa-Samuelson Effect in Central Europe: A Disaggregated Analysis." Paper presented at the 8th Dubrovnik Economic Conference, 27-29 June 2002.

Mongardini, J. (1998), "Estimating Egypt's Equilibrium Real Exchange Rate." Washington, IMF WP/ $98 / 5$.

The National Institute of Economic and Social Research (2003), "National Institute Global Econometric Model (NiGEM)." London, NIESR, http://www.niesr.ac.uk/models/nigem/nigem.htm.

Pain, N. Wakelin, K. (1998), "Export Performance and the Role of Foreign Direct Investment," Manchester School, Vol. 66, (Supplement), pp. 62-88.

Rahn, J. (2003), "Bilateral Equilibrium Exchange Rates of EU Accession Countries against the Euro." Helsinky, Bank of Finland BOFIT Discussion Papers No. 11.

Rider, M. (1994), "External Debt and Liabilities of Industrial Countries." Sydney, RBA Research Discussion Paper 9405.

Rubaszek, M. (2003), "The Optimal ERM II Central Parity for the Polish Zloty," Frankfurt, European Central Bank Paper presented at the 5th September Research Meeting "Equilibrium Exchange Rates in Accession Countries: Macroeconomic and Methodological Issues."

Sethi, D., Guisinger, S. E., Phelan, S. E., Berg, D. M. (2003), "Trends in Foreign Direct Investment Flows: A Theoretical and Empirical Analysis," Journal of International Business Studies, Vol. 34, pp. 315-326.

Stein, J. L., Allen, P. R. (1995), Fundamental Determinants of Exchange Rates. Oxford, New York: Oxford University Press, Clarendon Press.

Šmídková, K. et al. (1998), "Koruna Exchange Rate Turbulence in May." Prague, Monetary Policy Division Working Paper No. 2.

Šmídková, K., Barrell, R., Holland, D. (2002), "Estimates of FRERs for the Five EU Accession Countries." Prague, CNB Working Paper No. 3.

Williamson, J.(1994), Estimating Equilibrium Exchange Rates, Washington: Institute for International Economics.

WinSolve (2003), Version 3, A computer package for solving non-linear models Available via the Internet: http://www.econ.surrey.ac.uk/winsolve/. 